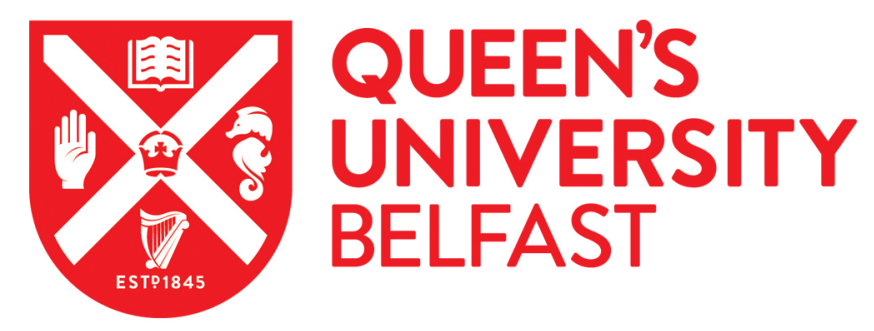

\title{
DNA double strand break repair: a radiation perspective
}

Kavanagh, J. N., Redmond, K. M., Schettino, G., \& Prise, K. M. (2013). DNA double strand break repair: a radiation perspective. Antioxidants \& Redox Signaling, 18(18), 2458-2472. https://doi.org/10.1089/ars.2012.5151

\section{Published in:}

Antioxidants \& Redox Signaling

\section{Document Version:}

Peer reviewed version

Queen's University Belfast - Research Portal:

Link to publication record in Queen's University Belfast Research Portal

Publisher rights

(C) 2013 Mary Ann Liebert, Inc.

DOI: 10.1089/ars.2012.515

This work is made available online in accordance with the publisher's policies. Please refer to any applicable terms of use of the publisher.

\section{General rights}

Copyright for the publications made accessible via the Queen's University Belfast Research Portal is retained by the author(s) and / or other copyright owners and it is a condition of accessing these publications that users recognise and abide by the legal requirements associated with these rights.

Take down policy

The Research Portal is Queen's institutional repository that provides access to Queen's research output. Every effort has been made to ensure that content in the Research Portal does not infringe any person's rights, or applicable UK laws. If you discover content in the Research Portal that you believe breaches copyright or violates any law, please contact openaccess@qub.ac.uk. 
Kavanagh et al.

\section{INVITED FORUM REVIEW}

Title: DSB Repair - A radiation perspective

\section{Author List:}

Joy N. Kavanagh ${ }^{1 \star}$, Kelly M. Redmond ${ }^{1 \star}$, Giuseppe Schettino ${ }^{1}$ and Kevin M. Prise ${ }^{1 \#}$

${ }^{1}$ Centre for Cancer Research \& Cell Biology, Queen's University Belfast, 97 Lisburn Road, Belfast, BT9 7BL

\# Corresponding author

Centre for Cancer Research \& Cell Biology

Queen's University Belfast

97 Lisburn Road

Belfast,

BT9 7BL

Tel. 00442890972760

E-mail: k.prise@qub.ac.uk

*These authors contributed equally to this work.

Word count: 6965

N Figures: 6 (colour) 
Kavanagh et al.

\begin{abstract}
Significance: Ionising radiation can induce a wide range of unique DNA lesions due to the spatio-temporal correlation of the ionisation produced. Of these DNA DSB play a key role. Complex mechanisms and sophisticated pathways are available within cells to restore the integrity and sequence of the damaged DNA molecules.
\end{abstract}

Recent Advances: Here, we review the main aspects of the DNA DSB repair mechanisms with emphasis on the molecular pathways, radiation induced lesions and their significance for cellular processes.

Critical Issues: Although the main characteristics and proteins involved in the two DNA DSB repair processes present in eukaryotic cells (homologous recombination and non-homologous end joining) are reasonably well established, there are still uncertainties regarding the primary sensing event and their dependency on the complexity, location and time of the damage. Interactions and overlaps between the different pathways play a critical role in defining the repair efficiency and determining the cellular functional behaviour due to unrepaired/miss-repaired DNA lesions. The repair pathways involved in repairing lesions induced by soluble factors released from directly irradiated cells may also differ from the established response mechanisms.

Future Directions: An improved understanding of the molecular pathways involved in sensing and repairing damaged DNA molecules and the role of DSB is crucial for the development of novel classes of drugs to treat human diseases and to exploit characteristics of ionising radiation and alterations in tumour cells for successful radiotherapy applications. 
Kavanagh et al.

\section{Innovation}

DNA double-strand breaks, where both strands of the double helix are broken are potentially very harmful to cells. Ionising radiations are very effective at producing DSB alongside other DNA lesions and cells have evolved pathways to try and remove these lesions. These detect the presence of damage then activate different repair pathways. Oxygen dependent reactive free radicals can also lead to DSB during DNA synthesis. Cells can also communicate between each other by bystander signals which can lead to indirect DSB. These pathways are being exploited to improve the efficiency of radiotherapy in combination with DSB repair inhibitors. 


\section{Introduction to radiation-induced DNA damage and repair}

All cells have extensive DNA repair mechanisms, which have evolved to maintain the stability of their genomes. This includes dealing with the consequences of DNA damage either from endogenous or exogenous sources. A careful balance must be maintained between the effective repair of DNA damage leading to genetic stability and survival, as the consequence of defective or incomplete repair can be genetic instability, which may lead to genetic divergences or disease such as cancer and other hereditary disease (96). Much of the endogenous DNA damage comes from reactive oxygen species produced during normal oxidative metabolism, which leads to increased levels of oxidised base damage (70). Estimates of endogenous damage as high as 10,000 DNA damages per cell per day (72) have been reported although there are significant uncertainties over the measurements of these with recent work suggesting specific lesions are at much lower levels (42). Replication errors can also occur, leading to either the wrong or a modified base being incorporated. Finally, cells can be exposed to a range of exogenous environmental sources of DNA damage including ionising radiation (IR), ultraviolet (UV) radiation and multiple types of different chemicals, such as inhibitors of topoisomerase II and the radiomimetic agent bleomycin. Of these, ionising radiations prove to be significant challenges to genome stability, due to their ability to induce a range of different types of DNA damage and because these have distinct spatial patterns due to the type of radiation exposure.

IR induced DNA damage includes single DNA strand breaks (SSBs), double DNA strand breaks (DSBs) and base modifications such as oxidation, alkylation, deamination, loss of bases residues to produce apurinic or apyrmidinic sites (AP sites), all of which can indirectly lead to SSBs and/ or DSBs. There are also crosslinks formed involving DNA-DNA and DNA-protein interactions (see figure 1 ).

The most critical of these lesions in terms of lethality and mutation probability is the DSB, which is considered to be a form of "complex DNA damage" also termed clustered damage or multiply damaged sites (132). Complex DNA damage is usually described as two or more lesions within one to two helical turns of the DNA arising from a single radiation track and distinct from endogeneous DNA damage (46). IR causes DNA lesions by direct interaction 
Kavanagh et al.

with DNA or indirectly via the generation of reactive species. In the case of Xrays, most DNA damage induced occurs via the latter method. Studies of DSB induction in mammalian cells exposed to $X$-rays suggest that $\sim 70 \%$ of the total DSBs result indirectly by interaction of reactive oxygen, such as hydroxyl radicals, that are generated by the ionisation of other molecules, such as water, in close proximity to the DNA. In contrast, heavy ions have a higher probability of a particle traversal directly causing a DSB and therefore rely less on radical species for DNA damage induction.

This review will cover key aspects of the induction, sensing and repair of DSBs caused by IR. Aside from the aspects of complex damage, most of the sections covered are of relevance to other agents that induce DSB directly or indirectly.

\section{Sensing DNA double strand breaks}

In order for the DSB repair mechanisms (described in section 3) to be successfully carried out, the DNA damage needs to be detected, cell cycle arrest must be induced and the lesion can then be repaired. This process is known as the DNA damage response (DDR), which involves interplay between three distinct sets of proteins as proposed by Jackson et al. (57). Damage is initially detected by sensor proteins, which recognise sites of damage within the DNA. These sensor proteins are recruited to damaged sites and amplify the damage signal to a set of proteins known as transducers which function to relay the signal to downstream effector proteins (12) (see figure 2). It is the activated effector proteins which then function to induce cell cycle arrest, DNA damage repair or apoptosis (57).

Despite the method ultimately used to repair the damage (HR or NHEJ), DSBs are initially sensed by the Mre11-Rad50-Nbs1 (MRN) complex. This highly conserved complex also has a role in the processing and repair of DSBs (see section 3) (123). Each of the proteins within this complex has different functions in DNA damage signalling. Mre-11 is a 70-90 kDa protein which possesses DNA binding activity and appears to function to recruit other DNA repair proteins to the site of DNA damage. It also has DNA endonuclease and exonuclease activity (25). Rad50 is a $150 \mathrm{kDa}$ protein that directly interacts with Mre11 (59) and functions to partially unwind double stranded DNA termini, enabling other proteins to access the site of damage and carry out repair functions. Finally, Nbs1 is a $65-85 \mathrm{kDa}$ protein that binds to phosphorylated proteins via its $\mathrm{N}$-terminus, thereby allowing the recruitment of various DNA 
Kavanagh et al.

damage repair and checkpoint control proteins to the site of DNA damage. Therefore, this complex functions both to detect damage and control checkpoint signalling in both HR and NHEJ repair pathways. Recent studies have indicated that MRN may be recruited to DNA DSBs by the single stranded binding protein hSSB1 that has a high affinity for short regions of SSDNA at broken DSB ends (101). Recruitment of hSSB1 to IR induced DSBs precedes MRN recruitment and, through a direct interaction with Nbs1, hSSB1 mediates MRN recruitment to DSB sites $(102,103)$.

Following DNA damage recognition by the MRN complex, activation of a series of transducer and effector proteins occurs to form the DDR. ATM (Ataxia telangiectasia mutated), another primary sensor of DNA double strand breaks, is recruited to sites of DNA damage by the MRN complex, inducing the autophosphorylation of ATM at ser 1981 and its activation. Deficiency of the ATM gene results in the neurodegenerative disorder ataxia telangectasia (AT) (108). AT is characterized by neurodegeneration, high risk of cancer and hypersensivity to IR, a discovery that lead to the proposal of its key role in detection and repair of DNA DSBs. In undamaged cells, ATM exists as inactive homodimers and multimers. Phosphorylation of ATM at ser 1981 allows dissociation of these into monomers with kinase activity capable of downstream signalling (7). ATM can then phosphorylate the histone variant 2AX (H2AX) at ser 139 up to $\sim 1 \mathrm{Mb}$ on either side of a DSB to form $\mathrm{YH} 2 \mathrm{AX}$, which forms foci at the sites of damage that are visible by fluorescent microscopy (105). H2AX can also be phosphorylated by the other PI3-kinase like proteins ATR (ataxia telangiectasia and Rad3-related protein), which is primarily activated at stalled replication forks (130), and DNA-PK (DNA protein kinase) (90), which is required for NHEJ. Phosphorylation of ATM, ATR and H2AX leads to an amplification of the DNA damage signal and the recruitment of a large number of DNA repair and checkpoint control proteins to the site of DNA damage, including Mediator of Damage Checkpoint protein 1 (MDC1) (114,115), p53 binding protein (53BP1) (131), Breast Cancer Susceptibility protein 1 (BRCA1) $(21,136)$, Chk1 (140), Chk2 $(2,35)$ and p53 (18) (see figure 2). Also recruited are members of the Fanconi anemia (FA) family of proteins such as FANCD2 (118), which co-operate with BRCA1 and BRCA2 in the FA/BRCA DNA repair pathway. A core complex of 8 FA proteins is recruited to sites of DNA damage, leading to ubiquitation of FANCD2 and recruitment of BRCA2 and RAD51 (65). Depending on the proteins recruited, the cell can undergo a number of fates, 
Kavanagh et al.

including cell cycle arrest, DNA repair via HR or NHEJ, apoptosis if the damage cannot be repaired, or senescence (96).

Recruitment of the MRN complex, phosphorylation of ATM and the subsequent phosphorylation of $\mathrm{H} 2 \mathrm{AX}$ occur within minutes of DNA DSBs being induced. The localisation of the MRN complex to sites of DNA damage has been shown to be upstream of ATM phosphorylation and localisation, as silencing of MRN proteins results in impaired ATM signalling $(19,122)$. However, the interactions between ATM and the MRN complex are not fully understood, as MRN seems to be required for the recruitment and activation of ATM, but ATM also appears to phosphorylate members of the MRN complex, allowing further downstream signalling (122). Recruitment of ATM may be through an interaction of its phosphatidylinositol 3-kinase (PI3-K) domain with the C-terminal of Nbs1 (34). ATM is not only activated in response to IR induced DNA DSBs. Conditions that alter chromatin structure such as exposure to topoisomerases also initiate ATM autophosphorylation, however, under these conditions many of the key DDR substrates of ATM (such as H2AX, MDC1, SMC1) are not phosphorylated indicating that amplification of the DNA damage signal cascade by ATM through its downstream effectors requires recruitment of ATM to DSB sites (68).

Some studies suggest that ATM may be targeted to sites of DSBs by the monoubiquitination of $\mathrm{H} 2 \mathrm{AX}$ by the BMI1/RNF2/RING1 E3 ligase complex (135). H2AX is then further di- or polyubiquitinated by RNF8 thus allowing recruitment of the BRCA1/RAP80 complex, which is required for DNA repair. ATM also stabilises hSSB1 by phosphorylation at theronine 117 in response to IR (101).

\section{DNA double strand break repair mechanisms}

DNA DSBs consist of two SSBs within one helical turn on opposing strands of DNA. IR induced DNA DSBs are not usually simple lesions but rather contain multiple complex lesions and overhanging ends (or ragged ends) of DNA that cannot be ligated directly and therefore must be removed before repair can begin.

DSBs are primarily repaired by one of two pathways, homologous recombination (HR) or non-homologous end joining (NHEJ), irrespective of 
Kavanagh et al.

their cause (see sections 4 and 5). Although the reasons why one repair pathway may be chosen over the other are not fully understood, the choice is thought to depend on the phase of the cell cycle, the presence of an intact sister chromatid, cell type (110), chromatin complexity (45) and the complexity of damage induced (87) (see section 4).

$\mathrm{HR}$ requires the presence of an intact sister chromatid as a template and thus this pathway is only available during late $S$ and $G 2$ phases (53). Therefore during G1 (and early S-phase) when this option is not available DNA DSBs are repaired by NHEJ. Although HR is considered to be relatively error free DNA repair method, even in the presence of a homologous chromatid, repair factors of each pathway compete for binding to DNA DSBs.

\section{a. Homologous recombination repair of IR induced DNA DSBS}

The major event that determines the decision for repair by HR is DNA end resection. A crucial event therefore is binding and activity of the MRN complex that was described in section 2. The MRN complex binds to DNA at the site of a lesion, recruiting and activating $\operatorname{ATM}(1,28,7)$. The endonuclease activity of Mre11 then facilitates 5'-3' resection to produce 3' single stranded DNA ends $(58,138)$. This endonuclease activity is regulated by an interaction with the CtBP-interacting protein (CtIP) in an ATM and BRCA1 dependent manner (107).

Following the formation of long tails of 3' sSDNA regions hSSB1 molecules are initially bound then displaced by replication protein A (RPA) to begin the formation of nucleoprotein filaments that will eventually invade the homologous DNA strand of the sister chromatid. A soft X-ray microbeam has been employed to show that binding of the hSSB1 protein to resected 3' SSDNA ends not only occurs before RPA binding but is required for the RPA focus formation- thus elucidating an early step in the HR pathway (102). RPA is activated in response to IR by extensive phosphorylation (66) and plays a crucial role in DNA damage checkpoint signalling, control of DNA replication as well as each of the main DNA repair mechanisms (143).

The RAD52/BRCA2/RAD51/RAD54 complex is then recruited to the sSDNA by a BRCA1/PALB2 (partner and localiser of BRCA2) complex. This facilitates the replacement of RPA with RAD51, thus stabilising the filament and catalysing 
Kavanagh et al.

the invasion into the sister chromatid and subsequent Holliday junction formation $(55,78)$. Additionally, direct binding of RAD52 to the ends of DSB lesions protects them from exonuclease activity. These vital roles of RAD52 in HR may indicate that it plays an important part in the decision for DSB repair by HR versus NHEJ (51). RAD51 focus formation can be observed in cells after exposure to IR. This focus formation does not occur in cells deficient for RAD54, and HR in these cells is less efficient (32).

To facilitate invasion into the sister chromatid strand, the two chromatids are tethered together by the structural maintenance of chromosomes proteins (SMC) 1, 3, 5 and 6 (also called cohesins) (40). Following invasion to the sister chromatid, the two strands are aligned with homologous regions within the sister chromatid. DNA synthesis, catalysed by DNA polymerase $\delta$, occurs from the 3' end to replace the sequence of DNA disrupted by the break. Once this DNA replication is complete the Holliday junction is resolved by DNA resolvases through a complex process that remains unclear (56). Finally, the DNA ends are ligated (55).

\section{b. Non-homologous end joining repair}

In late S and G2 phase HR competes with NHEJ and in G1 cells the latter, a relatively more error prone process, dominates. The key factors involved in NHEJ are the Ku70/Ku80 heterodimer (Ku), the catalytic subunit of DNAdependent protein kinase (DNA-PKcs), the nuclease Artemis, XRCC4, DNA ligase IV and XRCC4-like factor (XLF). As IR induced DNA DSBs frequently contain overhangs and often have phosphate or phosphoglycolate groups bound to their 3' ends, these require processing by additional factors such as the DNA polymerases $\mu$ and $\lambda$, polynucleotide kinase/phosphatase (PNKP) and Werner's syndrome helicase (WRN) before ligation can take place (76). The processing of these unligatable ends may result in base loss from either strand and is likely to be the reason that that NHEJ is error-prone. For a comprehensive discussion of protein and DNA interactions involved in NHEJ see $(76,94)$.

The first step in this pathway is the rapid recruitment of Ku to IR induced DNA DSBs (127) which occurs within a few seconds of irradiation (67). Ku70 and Ku80 together form a DNA binding core that has a high affinity for DNA without sequence specificity. This may explain the almost instantaneous recruitment of 
Kavanagh et al.

this complex to break sites. Shortly after recruitment to break sites $\mathrm{Ku}$ translocates along the DNA leaving the ends accessible for processing. Binding of $\mathrm{Ku}$ results in conformational changes in the C-terminal regions of both Ku70 and Ku80. This further acts to recruit the other key NHEJ players to sites of DSBs. Two DNA-PKcs molecules are recruited to each DNA DSB via an interaction with the C-terminal region of Ku80 (111). These two molecules tether the DNA ends together and that interaction stimulates their kinase activity. This interaction of two DNA-PKcs molecules tethering the extreme ends of the broken DNA is often referred to as the "synaptic complex" (27). DNA-PK is then phosphorylated at more than 16 sites via autophosphorylation and potentially by other kinases such as ATM and ATR. The protein kinase activity of DNA-PKcs that is 'switched on' by its interaction with DNA and Ku is thought to be a necessary step in NHEJ repair. Autophosphorylation of the ser 2023-2056 PQR cluster and the thr 2609-2647 ABCDE cluster of DNA-PKcs is required for repair of IR induced DNA DSBs (20). There is also cross-over at this point between the NHEJ and HR pathways. Deficiency of DNA-PKcs results in high radio sensitivity (81). Cells in which DNA-PKcs was mutated so that key autophosphorylation events were inhibited had reduced capacity to undergo HR and were more radiosensitive (4). Therefore the kinase function of DNA-PKcs has a criticial role in repair of IR induced DNA DSBs. That function is believed to be important for its release from DNA DSBs and laser microirradiation studies have shown that when DNA-PKcs lacked this function it was retained longer at the sites of DNA damage (120).

Once DNA ends have been secured they require processing to remove ragged ends. The specific enzymes that carry out this processing depend on the complexity of the breaks, whether gaps in the DNA need to be filled and what groups are blocking the ends of the DNA. The exact timing of DNA end processing in NHEJ and the order of recruitment of many factors remains unclear but the most likely key players in this stage of NHEJ are summarised next.

The nuclease Artemis has 5'-3' exonuclease activity and acquires endonuclease activity in the presence of DNA-PKCs and adenosine triphosphate (ATP). The inactivation of the enzyme Artemis causes radiationsensitive severe immunodeficiency indicating that it must have a role in repair of radiation induced DNA damage. However, cells lacking Artemis still have 
some DSB repair suggesting that it is only required for the repair of a subset of breaks (see section 5 for more on this). One proposed mechanism of recruitment of Artemis during NHEJ is by an interaction with DNA-PKcs. Proper function of Artemis in NHEJ requires the activation of its endonuclease function. Exactly how this occurs remains unclear however, in vitro Artemis has been shown to be a phosphorylation target of both DNA-PKcs and ATM. Artemis has a role in the processing of IR induced DNA DSBs with DNA hairpin loops, 3'-phosphoglycolate groups and functions in the repair of complex lesions in an ATM dependent manner (76).

Polynucleotide kinase (PNK) is phosphorylated in response to IR although the kinase responsible is unknown (79). Knock down of PNK results in increased IR sensitivity, most likely due to defective NHEJ DSB repair (62). PNK is involved in the removal of non-ligatable ends at the termini of DSBs. It's DNA phosphatase and DNA kinase activities are key to this function. PNK may be recruited to DNA DSBs by an interaction with phosphorylated XRCC4. DNA polymerases $\mu$ and $\lambda$ are recruited to sites of IR induced DSBs by their interaction with $\mathrm{Ku}$ (and possibly XRCC4-DNA ligase IV) and are required to fill gaps in the DNA created during the removal of ragged DNA ends. Their function in NHEJ is thought to be mainly through their respective BRCA1 Cterminus (BRCT) domains. DNA pol $\lambda$ is phosphorylated in response to IR (79). Which DNA pol is required depends largely on whether a DNA template is required. While DNA pol $\lambda$ normally requires a template to fill gaps, DNA pol $\mu$ can direct template-independent-synthesis across a DSB with no terminal microhomology (86). Loss even of both these polymerases does not confer significantly increased sensitivity to IR, therefore it seems that they are required for the repair of only a small subset of IR induced DSBs (92).

Aprataxin and PNK like factor (APLF) also has both exonuclease and endonuclease activity, is phosphorylated by ATM, interacts with $\mathrm{Ku}$ and its downregulation results in defective DSB repair. These findings together suggest a role for APLF in NHEJ repair. There is also evidence that The Werner's Syndrome protein (WRN) may have a role in NHEJ. WRN is a RecQ helicase that has a number of functions that would be useful in processing nonligatable DNA ends. These include 3'-5' exonuclease, 3'-5' DNA helicase, strand annealing and DNA-dependent ATPase activities. Its exonuclease activity is stimulated by its interactions with $\mathrm{Ku}$ and the XRCC4-DNA ligase IV 
Kavanagh et al.

complexes. Finally, loss of WRN activity in vivo is associated with cancer predisposition, premature aging and genomic instability thus suggesting a role in DNA damage repair.

In order to complete the repair of DNA DSBs the processed ends must be ligated. In NHEJ this is done by the XRCC4-DNA ligase IV-complex. Although XRCC4 is required for NHEJ it has no enzymatic function on its own but instead acts as a scaffold bringing other factors to sites of DSBs (61). XRCC4 has a $\alpha$-helical region that interacts with a linker region between the two $\mathrm{C}$ terminal BRCT domains of DNA ligase IV (48). This forms a very stable complex that stabilises the activity of DNA ligase IV and via the interaction of XRCC4 with Ku brings it close to DNA ends requiring ligation (47). It has been proposed that in response to DNA DSBs, XRCC4 is phosphorylated by DNAPKcs and that this stabilises the complexes position at the break site and promotes ligation. Ligation however, is not dependent on that phosphorylation. The nuclear localisation of XRCC4 and its role in DSB repair is also dependent on its SUMO-ylation. Further to DNA end ligation by the XRCC4-DNA ligase IV complex, XLF is also required for a subset of DNA lesions where the processed ends are incompatible. The recruitment of XLF to DNA ends is independent of, but is stabilised by the XRCC4-DNA ligase IV complex.

\section{c. Alternate-Non-homologous-end-joining}

An alternative end-joining pathway may be employed when some parts of the NHEJ pathway are missing or mutated. There is cross over between this pathway and some components of HR and SSB repair (80) pathway is able to ligate broken DNA ends in the absence of DNA-PKcs, XRCC4 and DNA ligase IV. Instead this pathway may employ PARP1, XRCC1 and DNA ligase III (128). In this case PARP1 may bind the DNA DSB and stimulate fusion. The XRCC1/ligase III complex then ligates the DNA ends. When $\mathrm{Ku}$ is present it blocks the access of PARP1 to DSBs. Thus alternative end-joining only occurs in NHEJ-deficient cells (129).

\section{Choice of repair pathway}

Following IR induced DNA DSB induction, in cells in G1 or S/G2 phase there is competition for binding to the lesion by Ku and the MRN complex. The outcome of that competition in S-phase dictates the DNA damage repair pathway. 
Kavanagh et al.

Binding of MRN and its activation and recruitment of ATM commits cells to repair by HR, whereas successful binding of Ku70-Ku80 takes repair down the NHEJ route. Localisation of the MRN complex at DSBs is independent of the cell cycle phase (94). A further interaction that may dictate the choice of repair pathway in late S-phase is that of 53BP1 and BRCA1. 53BP1 binds DNA near sites of DSBs and 53BP1 focus formation can be observed by fluorescence microscopy after IR exposure. It may have a role in inhibiting end resection by binding to dimethyl-histone $\mathrm{H} 4$ Lys2O and tethering DNA ends to facilitate ligation. The prevention of DNA end resection by 53BP1 indicates that 53BP1 binding may favour repair by NHEJ. Conversely, it is thought that BRCA1 can counteract the action of 53BP1 but the mechanism is unclear (13).

There is increasing evidence that DSB repair rate and choice of repair mechanism are dependent on chromatin complexity. DSBs that are repaired slowly may be in regions of heterochromatin that require prolonged chromatin relaxation for repair intermediates to access break sites. It has been shown experimentally that sustained activation and localisation of ATM at these break sites is crucial for this and that ATM functions in this process to activate KRABassociated protein (KAP-1). pKAP-1 forms persistent foci that co-localise with $\mathrm{Y}-\mathrm{H} 2 \mathrm{AX}$ and these are thought to represent DSBs in heterochromatin. The same study also suggested that DSBs in regions of heterochromatin are repaired in G2 phase by an Artemis dependent HR pathway. In contrast most DSBs in euchromatic regions were repaired during $\mathrm{G} 2$ by $\operatorname{NHEJ}(142,45)$.

\section{DSB and radiation quality}

\section{a. Complex lesions}

The type of DNA lesions that result from cellular exposure to IR is heterogeneous and in general the complexity of breaks strongly depends on the characteristics of the incident radiation. The term "radiation quality" is commonly used to discriminate the density of ionisations produced along the path of a charged particles track as this is correlated with the density of DNA lesions caused. Linear energy transfer (LET) is the amount of energy per unit distance that is transferred by a particle to the surrounding medium along its trajectory. This factor depends on the charge and kinetic energy of the particle and is normally reported in units of keV/um. In first approximation, the LET is inversely proportional to the square of the particle kinetic energy, 
proportional to the square of the particle charge and independent from its mass as indicated by the Bethe-Block formula (9);

$-\frac{d E}{d x}=\frac{4 \pi}{m_{e} c^{2}} \cdot \frac{n z^{2}}{\beta^{2}} \cdot\left(\frac{e^{2}}{4 \pi \varepsilon_{0}}\right)^{2} \cdot\left[\ln \left(\frac{2 m_{e} c^{2} \beta^{2}}{I \cdot\left(1-\beta^{2}\right)}\right)-\beta^{2}\right]$

$\mathrm{v}=$ velocity of the particle

$\mathrm{C}=$ speed of light

$\beta=v / c$

$E=$ energy of the particle

$x=$ distance travelled by the particle

$Z=$ particle charge

$\mathrm{e}=$ charge of the electron

$\mathrm{m}_{\text {erest }}=$ mass of the electron

$\mathrm{n}=$ electron density of the target

$\mathrm{I}=$ mean excitation potential of the target

$\varepsilon_{0}=$ vacuum permittivity

Although LET is a quantity defined for charged particles, an LET value can also be calculated for $X$-rays leading to an average value of $2 \mathrm{keV} / \mu \mathrm{m}$ for 250 $k \vee p$ X-rays. LET is therefore an indication of the ionization pattern (i.e. track structure) produced by a particle beam at a certain energy (141). The pattern of DNA damage caused by a particle traversal is directly related to the LET and track structure of the particle beam. As the primary charged particle traverses a cell it causes ionisations itself that are capable of causing DNA DSBs due to their spatial and temporal proximity. These ionisations generate secondary delta electrons that have tracks away from the trajectory of the primary particle. The delta electrons are able to cause further ionisations. The result is a penumbra around the primary particle path the width of which increases with increasing energy of the primary particle. As charged particles slow down (lose energy) the track length of the delta electrons also decreases so the pattern of ionisations has a higher density (and LET) near the end of the primary particles' path. This corresponds with the peak of energy deposition for charged particles known as the 'Bragg peak'.

For charged particles, particularly heavy ions, the probability of causing complex, or 'clustered' DNA damage increases as LET increases and therefore as a given particle slows down. Complex DNA damage caused by high LET radiation is believed to be more difficult for the cell to repair and 
therefore more lethal. An excess of small DNA fragments $(<3 \mathrm{Mb})$ have been observed using pulsed field gel electrophoresis (PFGE) of DNA after irradiation of human fibroblasts with charged particles of different LET (80$300 \mathrm{keV} / \mu \mathrm{m})$. This was not observed after low LET irradiation. These small fragments may be created as a result of intra-track ionisations (112).

A DSB is a type of clustered lesion as these breaks are usually formed from two DNA lesions on opposite strands within 10 base pairs of each other. However 'complex' DNA DSBs can also involve two or more breaks on each DNA strand within 10 base pairs (23). DSBs induced by high LET ions are $\sim 70 \%$ complex DSBs and 30\% simple DSBs, compared to low LET particles such as X-rays that cause only 30\% complex DSBs. Clustered lesions also include non-DSB damage and are most likely made up of closely opposed SSBs and abasic damage sites (49). These complex lesions, that potentially occur at 4-8 fold higher yields than prompt DSB, are also less repairable than single lesions and can lead to a DSB during repair (30). Complex damages present a harder challenge for the cellular repair processes due to clustering of lesions and the loss of DNA fragments. Clustered DNA lesions are more likely to be misrepaired or unrepaired conferring an increased probability of chromosome aberrations, mutation and cell death for high LET radiation (5).

The main methods for studying induction and repair of DNA DSBs in radiobiology are PFGE and inspection of ionising-radiation-induced foci (IRIF) (see figure $4 \mathrm{a}$ and $\mathrm{b}$ ). Although historically the PFGE method has been used most frequently, IRIF based assays provide higher sensitivity thus enabling their use at radio-biologically relevant doses ( $<2 \mathrm{~Gy}$ ) and are a versatile platform for the study of DNA repair factor dynamics. The induction and resolution of IRIF has been employed for the investigation of the role of many factors involved in the sensing and repair of DNA DSBs, including but not restricted to pATM, 53BP1, BRCA1, yH2AX, MRN, RAD51 and DNA-PKcs (see figure 4.c for a schematic representation of IRIF resolution over time post IR exposure). With the advent of GFP (green fluorescent protein) and other live cell tags, it is now also possible to qualitatively and quantitatively monitor the DNA repair process in live cells and assess protein interaction and turnover at site of damage using techniques such as FRET (Forster Resonance Energy Transfer) and FRAP (Fluorescent Recovery After Photobleaching). The effectiveness of heavy charged particles for the induction of complex DNA DSBs has been shown using both methods $(94,6$, 
Kavanagh et al.

121). Imaging of IRIF has also shown that very early ( $<1 \mathrm{hr})$ after irradiation with high LET radiation, foci are larger and more intensely fluorescing compared to those resulting from X-irradiation (22). IRIF localise in stripes through cell nuclei along heavy ion tracks and the co-localisation of DNA repair factors involved in multiple repair processes suggests the highly complex nature of the lesions induced $(86,5)$. These complex lesions may include multiple DSBs, SSBs and abasic sites within close proximity that appear as a single larger and brighter focus but are repaired slower than those observed following low LET exposures (23).

\section{b. Mechanism for repair of high LET complex DSBS}

Repair kinetics studies have identified two specific components: a fast one which is responsible for the majority of the repair and which dominates the repair response in the immediate hours post-irradiation, and a slower component which protracts for 24 hrs and longer. It has also been shown that the slow phase of DNA repair is longer for high LET induced DNA DSBs than for low LET DSB. This is most likely due to a higher frequency of complex clustered damage that require additional processing before DNA ligation can occur and due to the presence of unrepairable lesions. Analysis of DNA rejoining by PFGE demonstrated an LET dependent increase in rejoining time up to $200 \mathrm{keV} / \mu \mathrm{m}(105,133)$. Studies of IRIF resolution kinetics has provided further evidence for the complex nature of high LET particle induced lesions. The disappearance of heavy ion induced foci is slower compared to $X$-rays, and heavy ion (such as $1 \mathrm{GeV} /$ nucleon Iron ion) exposures induce a proportion of foci that persist even beyond 48 hours after exposure $(87,6$, 121). These persistent foci are generally believed to represent unrepaired DSBs, however, these have also been associated with IR induced senescence and chromatin alterations $(116,115)$.

Precisely how high LET DNA DSB processing differs from that of simple DSBs is yet to be elucidated. The kinase ATM and nuclease Artemis have been associated with the repair of complex DNA DSBs $(99,72)$. Recent evidence suggests that complex clustered DNA damages that include DSBs with other DNA lesions close to them are processed in the slow phase of repair by a sub-pathway of NHEJ that is dependent on ATM, DNA-PKcs and $\mathrm{Ku}$ (98). That study showed that simple DSBs (induced by ultra soft X-rays) are repaired by an NHEJ pathway that does not require ATM or DNA-PKcs, in 
Kavanagh et al.

contrast those factors were necessary for repair of more complex lesions (induced by multi photon near-infrared microbeam). This is probably due to a necessity for extensive DSB end processing in these complex lesions. Finally, evidence suggests that slow kinetics of repair of high LET radiation lesions may be strongly influenced by chromatin complexity. Proposed methods for dealing with heterochromatic DSBs are described in section 3.

\section{DSB and replicative stress}

\section{a. Oxidative stress induced DSB}

DNA DSBs arise following direct damage to DNA by IR. However, other mechanisms involving oxidative stress can also lead indirectly to DSB induction (see figure 5). Reactive oxygen species (ROS) can be produced in cells as a consequence of various cellular processes, including $\mathrm{CO}_{2}$ metabolism, stimulation of immune responses or release of cytokines and chemokines from neighbouring cells. ROS can have a number of different effects on carbohydrates, proteins, lipids and DNA (70), including causing the oxidation of purines and pyrimidines, AP DNA sites and SSBs. The majority of this damage is repaired using base excision repair (BER) or nucleotide excision repair (NER). BER is important for the removal of non-bulky modifications and abasic sites and involves removal of a damaged base by a DNA glycosylase, incision at the remaining site, addition of an undamaged base by DNA polymerase and finally re-ligation of the DNA by a DNA ligase. NER is important in repair of bulky base modifications which cause distortion of the DNA helix and requires the damage to be recognised by xeroderma pigmentosum (XP)/cockayne syndrome (CS) proteins, DNA unwinding and incision, addition of an undamaged base and ligation. However, it is estimated that approximately $1 \%$ of these single strand lesions are converted into DSBs (118), particularly at replication forks during DNA replication. Recognition of these DSBs differ from DSBs induced by direct IR in that ATR appears to play an important role, as well as ATM. They are then consequently repaired by NHEJ or HR.

b) Hypoxia

Relative oxygen concentrations within cells have also been reported to influence both levels of DNA damage induced and how this damage is repaired. Hypoxia within tumours has been associated with increased radioresistance and decreased disease-free survival (126). DNA repair pathways including HR and NHEJ have been shown to be less effective in 
hypoxic conditions (89). This is thought to be due to the alteration of expression of DNA DSB-associated genes (reviewed by (14)). Cellular responses to hypoxia are mediated primarily by the HIF (hypoxia inducible factor) family of transcription factors. DNA DSB repair proteins downregulated in response to hypoxia include BRCA1 (10), RAD51, RAD52 and BRCA2 (82). The result of this is that DNA DSB repair by HR is compromised in hypoxic conditions, potentially leading to an increase in biological effects including translocations or chromosomal deletions.

Oxidative stress may also positively or negatively impact on DNA damage recognition and repair. ATM has been shown to be activated by oxidation in the absence of either a DSB or MRN recruitment indicating that it may be a key mediator in the cellular response to oxidative stress (50), while DNA-PKcs which stabilises pP53, has been shown to be negatively regulated by Artemis during oxidative stress therefore preventing G1 arrest and apoptosis (139). Furthermore, repair of DSBs by NHEJ under conditions of oxidative stress is impeded due to an inability of Ku to bind to the lesion. This may be due to an oxidation mediated conformational change of $\mathrm{Ku}(8)$.

\section{c. Bystander effects}

DNA DSBs can also result following signalling from neighbouring cells that have been damaged by radiation. The radiation-induced bystander effect is defined as the ability of an untreated cell to respond to signals from a neighbouring irradiated cell (96). Bystander effects have been observed in a wide range of cell lines and in vivo (96). The damage can arise in two ways, either through intercellular communication via gap junctions, or via the release of soluble factors, which can travel to distant cells. The soluble factors released are dependent on the cell type which has been irradiated, but have been reported to include chemokines/cytokines $(29,91,109)$, death ligands (74), ROS (75), nitric oxide $(75,109)$, growth factors (29) and $\mathrm{Ca}^{2+}(75)$. Bystander effects are reported to be the result of increased ROS generation in nonirradiated cells as a consequence of signalling from irradiated cells, most likely due to increases in intracellular $\mathrm{Ca}^{2+}$ and subsequent mitochondrial depolarisation and ROS release (75). Endpoints for which bystander effects have been observed include DNA damage, mutations, terminal differentiation 
Kavanagh et al.

and apoptosis (reviewed by Prise and O'Sullivan (96)). DNA damage occurring in cells following bystander signalling differ from the responses of directly irradiated cells, with damage being detected at later timepoints. Bystanderinduced DNA damage is also primarily detected by ATR, with ATM found to act downstream of ATR in bystander cells (see figure 5$)(16,96)$.

\section{Targeting DSB repair in cancer therapy}

The aim of radiation therapy is to induce DNA damage in the form of DSBs, which ultimately leads to cell death within the tumour. However, resistance is a major mechanism limiting the effectiveness of radiotherapy as a cancer treatment. One way in which tumour cells can develop resistance to radiation treatment is by improving the effectiveness of DNA repair pathways, thereby enabling the cells to repair the damage and allowing the cells to survive and replicate. Targeting these repair pathways may therefore be a good therapeutic option to try to improve the effectiveness of radiation treatment.

\section{a. Expression of DNA damage repair proteins in cancer}

AT is a condition resulting from mutation of the ATM gene. It is characterised by a predisposition to cancer and very high cellular sensitivity to radiation treatment. As explained in sections 2 and 3, ATM plays a role early in the DNA damage response network, being one of the first proteins to be phosphorylated following DNA damage detection. It is therefore easy to see why loss of function of ATM can lead to an increased predisposition to cancer development, as loss of ATM has a major impact on the cells ability to repair damage efficiently. Mutations in ATM lead to a much higher risk of development of breast cancer $(98,119)$ and leukemia $(77)$, while also reducing time to recurrence. Mutation of ATM has also been reported to lead to an increased sensitivity to radiotherapy treatment (17), indicating that this protein may be important in radiation response.

Altered expression of other proteins in DNA repair pathways have been shown to both increase risks of developing cancer and influence the effectiveness of treatments designed to induce DNA damage. For example, overexpression of members of the FA family of proteins, which function to co-operate with BRCA1 and BRCA2 in DNA damage repair by HR, leads to a higher risk of developing various types of cancer, including breast cancer $(31,41,97,112,124)$, 
Kavanagh et al.

leukemia $(33,54)$ and pancreatic cancer $(24,52,60)$. In addition, low expression of FA proteins have been shown to predict response, with low FANCD2 expression associated with increased response of esophageal cancer patients to treatment with a combination of chemotherapy and radiotherapy (3). It is also widely known that mutations of the DNA damage repair proteins BRCA1 and BRCA2 significantly predisposes carriers to development of breast and ovarian cancer, with up to $85 \%$ of these tumours associated with changes in expression levels of BRCA1 or BRCA2 (39). BRCA status may also be important in patient outcome, with BRCA2 mutations reported to correlate with improved survival and chemotherapy response in ovarian cancer patients (137). PARP, which is important for detecting single strand DNA breaks, plays a key role in the response of HR defective cells to DNA damage, as unrepaired SSBs can be converted to DSBs which the cells cannot effectively repair. PARP is overexpressed in breast cancer compared to normal breast tissue, and its overexpression has also been correlated with high grade, tumour size and worse survival (44). These studies highlight the importance of DNA repair pathways in cancer treatment outcomes and the need to target these pathways in order to improve response rates.

\section{b. Therapeutic inhibition of DNA repair pathways}

Various inhibitors have been developed to target DNA repair proteins. A dual $\mathrm{PI3K} / \mathrm{mTOR}$ inhibitor, NVP-BEZ235, has been reported to potently inhibit both ATM and DNA-PKc, thereby inhibiting both HR and NHEJ pathways. This inhibitor has shown promising results, showing significant radiosensitisation in a panel of cell lines and in tumour xenograft models (85). In addition, this inhibitor is currently in Phase1/2 clinical trials for the treatment of solid tumours. Inhibition of ATM using different inhibitors has also shown to significantly increase sensitivity to radiation treatment (reviewed by (71)). Interestingly, the inhibition of ATR function in hypoxic cells, which show higher levels of radiation resistance, using the specific inhibitor VE-821 has been shown to sensitise these cells to radiation treatment, indicating that this approach may be important in a therapeutic setting for the treatment of tumours with hypoxic regions (93).

Chk1/Chk2 inhibitors have also been tested in combination with DNA damaging agents. The inhibitor AZD7762 has been used in pancreatic cancer cells both 
Kavanagh et al.

in vitro and in tumour xenograft models and has shown to be effective at inducing cell death and tumour regression both as a single agent and in combination with gemcitabine and radiation (84). Mitchell et al. have also shown that AZD7762 can sensitise a panel of human tumour cell lines to radiation treatment, and in addition can sensitise HT29 xenograft models to radiation with minimal side effects from treatment with the inhibitor both alone and in combination with radiation (83), indicating the potential of this inhibitor as a clinical agent. Other Chk inhibitors have also been shown to increase radiosensitivity of tumour cells, such as XL-844 (104) and PF-477736 (37), which has shown potential both as a single agent and in combination with DNA damaging agents (11).

\section{c. Synthetic lethality}

Many types of cancer arise from cells that have developed mutations in DNA DSB repair pathways. Alterations in these pathways allow cells to accumulate damage and other mutations but still retain their ability to divide. However, cells possess numerous DNA repair pathways, which can be activated following DNA damage. If one of these pathways is inactivated in tumour cells due to mutations of key proteins within the pathway, the tumour cells can become more dependent on other repair pathways to repair replication-associated and other types of DNA damage. This opens up important therapeutic options, as targeting the intact pathways should prevent the tumour cells from repairing any DNA damage incurred and allow the cells to undergo apoptosis. This concept has been named synthetic lethality (see figure 6).

Synthetic lethal interactions can be seen between a number of proteins, most notably in the use of PARP inhibitors in a BRCA mutant setting (36). Cells that have developed a mutation in BRCA1 or BRCA2 have defective HR function. Inhibition of PARP results in an accumulation of SSBs, which can be converted into DNA DSBs at replication forks. These DSBs cannot be repaired in HR deficient cells, resulting in the cells undergoing apoptosis. PARP inhibitors may be very useful in treatment of patients with tumours possessing BRCA mutations, as tumour cells have developed mutations in BRCA1 or BRCA2 while the surrounding normal tissue will not have these mutations. This means that the inhibitors should specifically target the tumour cells while sparing the 
surrounding normal cells (36), which have an intact HR pathway to repair the damage.

Inhibition of PARP has been shown to sensitise cells to radiation treatment (125). Importantly, the use of PARP inhibitors or PARP targeted siRNA as a single agent has been shown to result in a significant reduction in cell survival of BRCA2 mutant cells $(15,36)$. In addition, xenograft models developed from patient tumour samples have shown that PARP inhibitors induce significant apoptosis and reduce proliferation of BRCA2 mutant tumours, both as a single agent and in combination with DNA damaging agents, while BRCA2 wild-type tumours show greatly reduced responses to PARP inhibition (69). These studies and others have indicated the importance of PARP inhibitors as a treatment strategy, leading to the testing of PARP inhibitors in clinical trials. In a Phase I clinical trial, the PARP inhibitor olaparib was shown to exhibit antitumour activity in patients with BRCA1 or BRCA2 mutations while causing few adverse side effects (38). This inhibitor was also tested in Phase II clinical trials. Gelmon et al. reported that $41 \%$ of BRCA1 or BRCA2 mutant ovarian cancer patients showed a response following treatment with olaparib, compared to $24 \%$ of patients without mutations (43). However, another study reported that there was no statistically significant improvement in progression free survival in ovarian cancer patients with BRCA1 or BRCA2 mutations treated with the inhibitor (63). Astra Zeneca have withdrawn olaparib from Phase III trials after analysis of the data indicated that there was no improvement on overall survival following treatment of BRCA1 and BRCA2 mutant ovarian cancer patients. However, it is still being investigated in other disease settings, such as BRCA1/2 defective breast cancer. There are also other PARP inhibitors in various phases of clinical trials, including iniparib (which was the first PARP inhibitor to be tested clinically), rucaparib and veliparib.

PARP inhibitors also show synthetic lethality when combined with ATM mutations (134), as well as mutations in MRE11 and NBS1 (26). Synthetic lethal interactions are also observed between mutations of the FA family members and ATM inhibitors (64).

\section{Summary}


Kavanagh et al.

DNA double-strand breaks are critical lesions for cells which if not repaired can lead to a high probability of mutations and cell death. Taking ionising radiations as an example of an effective inducer of DNA DSB, lesion complexity, where additional damages are associated with a DSB due to the radiation track structure, is also important causing additional challenges for repair pathways. DSBs can also be produced indirectly via oxidative stress and the consequences of replication fork stalling, typically seen for ionising radiation induced bystander responses. Cells have evolved several options for sensing and repairing DSBs with the molecular mechanisms being defined. The restricted options of repair pathways available to tumour cells, when specific mutations in key repair enzymes are present, allows selective targeting of these particularly via synthetic lethality approaches. Our expanding knowledge of DSB induction, using ionising radiation as a paradigm, is providing new opportunities to target these in cancer therapy.

\section{Acknowledgements}

The authors are grateful to Cancer Research UK (C1513/A7047), MRC (G1100014), EPSRC (EP/1005714/1), Breast Cancer Campaign (2009MayPR03) and the European Commission (EPIRADBIO project No 269553) for funding their work. 
Kavanagh et al.

\section{List of Abbreviations}

$\begin{array}{ll}\text { 53BP1 } & \text { p53 binding protein 1 } \\ \text { AP } & \text { apurinic/apyrmidinic } \\ \text { APLF } & \text { aprataxin and PNK like factor } \\ \text { AT } & \text { ataxia telangectasia } \\ \text { ATM } & \text { ataxia telangectasia mutated } \\ \text { ATP } & \text { adenosine triphosphate } \\ \text { ATR } & \text { ataxia telangectasia and Rad3-related protein } \\ \text { BER } & \text { base excision repair } \\ \text { BMI1 } & \text { B lymphoma Mo-MLV insertion region 1 } \\ \text { BRCA } & \text { breast cancer susceptibility protein } \\ \text { BRCT } & \text { BRCA1 C-terminus } \\ \text { Chk } & \text { checkpoint kinase } \\ \text { CO2 } & \text { carbon dioxide } \\ \text { CS } & \text { cockayne syndrome } \\ \text { CtIP } & \text { CtBP-interacting protein } \\ \text { DDR } & \text { DNA damage response } \\ \text { DNA } & \text { deoxyribonucleic acid } \\ \text { DNA pol } & \text { DNA polymerase } \\ \text { DNA-PK } & \text { DNA protein kinase } \\ \text { DNA-PKcs } & \text { catalytic subunit of DNA-PK } \\ \text { DSB } & \text { double DNA strand break } \\ \text { FA/FANC } & \text { Fanconi anemia } \\ \text { FRAP } & \text { fluorescent Recovery after photobleaching } \\ \text { FRET } & \text { forster Resonance Energy Transfer } \\ \text { GeV } & \text { gigaelectron volt } \\ \text { GFP } & \text { green fluorescent protein } \\ \text { H2AX } & \text { histone variant 2AX } \\ \text { HR } & \text { homologous recombination } \\ \text { hr } & \text { hour } \\ \text { hSSB1 } & \text { human single stranded DNA binding protein 1 } \\ \text { IR } & \text { ionizing radiation } \\ \text { IRIF } & \text { ionizing radiation induced foci } \\ \text { kDa } & \text { kilo dalton } \\ \text { KAP-1 } & \text { KRAB-associated protein } \\ \text { keV } & \text { kilo electonvolts } \\ \text { Ku } & \text { Ku70/Ku80 complex } \\ \text { kVp } & \text { kilovoltage peak } \\ \text { LET } & \text { linear energy transfer } \\ \text { Lys } & \text { lysine } \\ \text { Mb } & \text { mega bases } \\ \text { MDC1 } & \text { mediator of damage checkpoint protein 1 } \\ \text { MRN } & \text { Mre11-Rad50-Nbs1 complex } \\ \text { mTOR } & \text { mammalian target of rapamycin } \\ \text { NER } & \text { nucleotide excision repair } \\ \text { NHEJ } & \text { non-homologous end-joining } \\ \text { PALB2 } & \text { partner and localiser of BRCA2 } \\ \text { PARP } & \text { poly ADP ribose polymerase } \\ \text { PFGE } & \text { pulsed field gel electrophoresis } \\ \text { RING1 } & \text { phosphatidylinositol 3-kinase } \\ & \text { polynucleotide kinase } \\ \text { polynucleotide kinase/phosphatase } \\ \text { really interesting new gene 1 }\end{array}$


Kavanagh et al.

$\begin{array}{ll}\text { RNF2 } & \text { RING finger protein } 2 \\ \text { ROS } & \text { reactive oxygen species } \\ \text { RPA } & \text { Replication protein A } \\ \text { Ser } & \text { serine } \\ \text { SiRNA } & \text { small interfering RNA } \\ \text { SMC } & \text { structural maintenance of chromosomes proteins } \\ \text { SSB } & \text { single strand DNA break } \\ \text { SSDNA } & \text { single stranded DNA } \\ \text { Thr } & \text { threonine } \\ \text { UV } & \text { ultra violet } \\ \text { WRN } & \text { Werner's syndrome helicase } \\ \text { XLF } & \text { XRCC4-like factor } \\ \text { XP } & \text { xeroderma pigmentosum } \\ \text { YH2AX } & \text { Phospho-serine-139-H2AX } \\ \mu \mathrm{Mm} & \text { micron } \\ & \\ < & \text { less than }\end{array}$




\section{References}

1. Abraham RT. PI 3-kinase related kinases: 'big' players in stress-induced signaling pathways. DNA Repair (Amst) 3: 883-7, 2004.

2. Ahn JY, Schwarz JK, Piwnica-Worms H, Canman CE. Threonine 68 phosphorylation by ataxia telangiectasia mutated is required for efficient activation of Chk2 in response to ionizing radiation. Cancer Res 60: 5934-6, 2000.

3. Alexander BM, Wang XZ, Niemierko A, Weaver DT, Mak RH, Roof KS, Fidias $\mathrm{P}$, Wain J, Choi NC. DNA repair biomarkers predict response to neoadjuvant chemoradiotherapy in esophageal cancer. Int J Radiat Oncol Biol Phys 83: 164-71, 2012.

4. Allen C, Halbrook J, Nickoloff JA. Interactive competition between homologous recombination and non-homologous end joining. Mol Cancer Res 1: 913-20, 2003.

5. Asaithamby A, Hu B, Chen DJ. Unrepaired clustered DNA lesions induce chromosome breakage in human cells. Proceedings of the National Academy of Sciences of the United States of America 108: 8293-8, 2011.

6. Asaithamby A, Uematsu N, Chatterjee A, Story MD, Burma S, Chen DJ. Repair of HZE-particle-induced DNA double-strand breaks in normal human fibroblasts. Radiat Res 169: 437-46, 2008.

7. Bakkenist CJ, Kastan MB. DNA damage activates ATM through intermolecular autophosphorylation and dimer dissociation. Nature 421: 499506, 2003.

8. Bennett SM, Neher TM, Shatilla A, Turchi JJ. Molecular analysis of Ku redox regulation. BMC Mol Biol 10: 86, 2009.

9. $\quad$ Bethe HA, Ashkin J. Experimental Nuclear Physics New York: J. Wiley; 1953.

10. Bindra RS, Gibson SL, Meng A, Westermark U, Jasin M, Pierce AJ, Bristow RG, Classon MK, Glazer PM. Hypoxia-induced down-regulation of BRCA1 expression by E2Fs. Cancer Res 65: 11597-604, 2005.

11. Blasina A, Hallin J, Chen E, Arango ME, Kraynov E, Register J, Grant S, Ninkovic S, Chen P, Nichols T, O'Connor P, Anderes K. Breaching the DNA damage checkpoint via PF-00477736, a novel small-molecule inhibitor of checkpoint kinase 1. Mol Cancer Ther 7: 2394-404, 2008.

12. Borst GR, McLaughlin M, Kyula JN, Neijenhuis S, Khan A, Good J, Zaidi S, Powell NG, Meier P, Collins I, Garrett MD, Verheij M, Harrington KJ. Targeted Radiosensitization by the Chk1 Inhibitor SAR-020106. International Journal of Radiation Oncology Biology and Physics (In Press), 2012.

13. Bouwman P, Aly A, Escandell JM, Pieterse M, Bartkova J, van der Gulden $H$, Hiddingh S, Thanasoula M, Kulkarni A, Yang Q, Haffty BG, Tommiska J, Blomqvist C, Drapkin R, Adams DJ, Nevanlinna H, Bartek J, Tarsounas M, Ganesan S, Jonkers J. 53BP1 loss rescues BRCA1 deficiency and is associated with triple-negative and BRCA-mutated breast cancers. Nat Struct Mol Biol 17: 688-95, 2010.

14. Bristow RG, Hill RP. Hypoxia and metabolism. Hypoxia, DNA repair and genetic instability. Nat Rev Cancer 8: 180-92, 2008.

15. Bryant HE, Schultz N, Thomas HD, Parker KM, Flower D, Lopez E, Kyle S, Meuth M, Curtin NJ, Helleday T. Specific killing of BRCA2-deficient tumours with inhibitors of poly(ADP-ribose) polymerase. Nature 434: 913-7, 2005.

16. Burdak-Rothkamm S, Rothkamm K, Prise KM. ATM acts downstream of ATR in the DNA damage response signaling of bystander cells. Cancer Res 68: 7059-65, 2008.

17. Byrd PJ, Srinivasan V, Last JI, Smith A, Biggs P, Carney EF, Exley A, Abson C, Stewart GS, Izatt L, Taylor AM. Severe reaction to radiotherapy for breast 
cancer as the presenting feature of ataxia telangiectasia. $\mathrm{Br} \mathrm{J}$ Cancer 106: 262-8, 2012.

18. Canman CE, Lim DS, Cimprich KA, Taya Y, Tamai K, Sakaguchi K, Appella E, Kastan MB, Siliciano JD. Activation of the ATM kinase by ionizing radiation and phosphorylation of p53. Science 281: 1677-9, 1998.

19. Carson CT, Schwartz RA, Stracker TH, Lilley CE, Lee DV, Weitzman MD. The Mre11 complex is required for ATM activation and the G2/M checkpoint. EMBO J 22: 6610-20, 2003.

20. Chan DW, Chen BP, Prithivirajsingh S, Kurimasa A, Story MD, Qin J, Chen DJ. Autophosphorylation of the DNA-dependent protein kinase catalytic subunit is required for rejoining of DNA double-strand breaks. Genes Dev 16: 2333-8, 2002.

21. Cortez D, Wang $Y$, Qin J, Elledge SJ. Requirement of ATM-dependent phosphorylation of brca1 in the DNA damage response to double-strand breaks. Science 286: 1162-6, 1999.

22. Costes SV, Boissiere A, Ravani S, Romano R, Parvin B, Barcellos-Hoff MH. Imaging features that discriminate between foci induced by high- and low-LET radiation in human fibroblasts. Radiation Research 165: 505-15, 2006.

23. Costes SV, Chiolo I, Pluth JM, Barcellos-Hoff MH, Jakob B. Spatiotemporal characterization of ionizing radiation induced DNA damage foci and their relation to chromatin organization. Mutation Research 704: 78-87, 2010.

24. Couch FJ, Johnson MR, Rabe K, Boardman L, McWilliams R, de Andrade M, Petersen G. Germ line Fanconi anemia complementation group $C$ mutations and pancreatic cancer. Cancer Res 65: 383-6, 2005.

25. D'Amours D, Jackson SP. The Mre11 complex: at the crossroads of dna repair and checkpoint signalling. Nat Rev Mol Cell Biol 3: 317-27, 2002.

26. Daemen A, Wolf DM, Korkola JE, Griffith OL, Frankum JR, Brough R, Jakkula LR, Wang NJ, Natrajan R, Reis-Filho JS, Lord CJ, Ashworth A, Spellman PT, Gray JW, Van't Veer LJ. Cross-platform pathway-based analysis identifies markers of response to the PARP inhibitor olaparib. Breast Cancer Res Treat 135: 505-17, 2012.

27. DeFazio LG, Stansel RM, Griffith JD, Chu G. Synapsis of DNA ends by DNAdependent protein kinase. Embo Journal 21: 3192-200, 2002.

28. Dery $U$, Masson JY. Twists and turns in the function of DNA damage signaling and repair proteins by post-translational modifications. DNA Repair (Amst) 6: 561-77, 2007.

29. Desai S, Kumar A, Laskar S, Pandey BN. Cytokine profile of conditioned medium from human tumor cell lines after acute and fractionated doses of gamma radiation and its effect on survival of bystander tumor cells. Cytokine, 61(1): 54-62, 2013.

30. Eccles LJ, O'Neill P, Lomax ME. Delayed repair of radiation induced clustered DNA damage: friend or foe? Mutation Research 711: 134-41, 2011.

31. Eelen G, Vanden Bempt I, Verlinden L, Drijkoningen M, Smeets A, Neven P, Christiaens MR, Marchal K, Bouillon R, Verstuyf A. Expression of the BRCA1interacting protein Brip1/BACH1/FANCJ is driven by E2F and correlates with human breast cancer malignancy. Oncogene 27: 4233-41, 2008.

32. Essers J, Hendriks RW, Swagemakers SM, Troelstra C, de Wit J, Bootsma D, Hoeijmakers $\mathrm{JH}$, Kanaar R. Disruption of mouse RAD54 reduces ionizing radiation resistance and homologous recombination. Cell 89: 195-204, 1997.

33. Faivre L, Guardiola P, Lewis C, Dokal I, Ebell W, Zatterale A, Altay C, Poole $\mathrm{J}$, Stones $\mathrm{D}$, Kwee ML, van Weel-Sipman M, Havenga $C$, Morgan $\mathrm{N}$, de Winter J, Digweed M, Savoia A, Pronk J, de Ravel T, Jansen S, Joenje H, Gluckman E, Mathew CG. Association of complementation group and mutation type with clinical outcome in fanconi anemia. European Fanconi Anemia Research Group. Blood 96: 4064-70, 2000. 
Kavanagh et al.

34. Falck J, Coates J, Jackson SP. Conserved modes of recruitment of ATM, ATR and DNA-PKcs to sites of DNA damage. Nature 434: 605-11, 2005.

35. Falck J, Mailand N, Syljuasen RG, Bartek J, Lukas J. The ATM-Chk2-Cdc25A checkpoint pathway guards against radioresistant DNA synthesis. Nature 410: 842-7, 2001.

36. Farmer $\mathrm{H}$, McCabe $\mathrm{N}$, Lord CJ, Tutt AN, Johnson DA, Richardson TB, Santarosa M, Dillon KJ, Hickson I, Knights C, Martin NM, Jackson SP, Smith GC, Ashworth A. Targeting the DNA repair defect in BRCA mutant cells as a therapeutic strategy. Nature 434: 917-21, 2005.

37. Ferrao PT, Bukczynska EP, Johnstone RW, McArthur GA. Efficacy of CHK inhibitors as single agents in MYC-driven lymphoma cells. Oncogene 31: 1661-72, 2012.

38. Fong PC, Boss DS, Yap TA, Tutt A, Wu P, Mergui-Roelvink M, Mortimer P, Swaisland H, Lau A, O'Connor MJ, Ashworth A, Carmichael J, Kaye SB, Schellens $\mathrm{JH}$, de Bono JS. Inhibition of poly(ADP-ribose) polymerase in tumors from BRCA mutation carriers. N Engl J Med 361: 123-34, 2009.

39. Ford D, Easton DF, Stratton M, Narod S, Goldgar D, Devilee P, Bishop DT, Weber B, Lenoir G, Chang-Claude J, Sobol H, Teare MD, Struewing J, Arason A, Scherneck S, Peto J, Rebbeck TR, Tonin P, Neuhausen S, Barkardottir R, Eyfjord J, Lynch H, Ponder BA, Gayther SA, Zelada-Hedman $\mathrm{M}$, et al. Genetic heterogeneity and penetrance analysis of the BRCA1 and BRCA2 genes in breast cancer families. The Breast Cancer Linkage Consortium. Am J Hum Genet 62: 676-89, 1998.

40. Fujioka Y, Kimata Y, Nomaguchi K, Watanabe K, Kohno K. Identification of a novel non-structural maintenance of chromosomes (SMC) component of the SMC5-SMC6 complex involved in DNA repair. Journal of Biological Chemistry 277: 21585-91, 2002.

41. Garcia MJ, Fernandez V, Osorio A, Barroso A, Fernandez F, Urioste M, Benitez J. Mutational analysis of FANCL, FANCM and the recently identified $\mathrm{FANCl}$ suggests that among the 13 known Fanconi Anemia genes, only FANCD1/BRCA2 plays a major role in high-risk breast cancer predisposition. Carcinogenesis 30: 1898-902, 2009.

42. Gedik CM, Collins A. Establishing the background level of base oxidation in human lymphocyte DNA: results of an interlaboratory validation study. Faseb Journal 19: 82-4, 2005.

43. Gelmon KA, Tischkowitz M, Mackay H, Swenerton K, Robidoux A, Tonkin K, Hirte $H$, Huntsman D, Clemons M, Gilks B, Yerushalmi R, Macpherson E, Carmichael J, Oza A. Olaparib in patients with recurrent high-grade serous or poorly differentiated ovarian carcinoma or triple-negative breast cancer: a phase 2, multicentre, open-label, non-randomised study. Lancet Oncol 12: 852-61, 2011.

44. Goncalves A, Finetti $P$, Sabatier R, Gilabert $M$, Adelaide J, Borg JP, Chaffanet M, Viens P, Birnbaum D, Bertucci F. Poly(ADP-ribose) polymerase1 mRNA expression in human breast cancer: a meta-analysis. Breast Cancer Res Treat 127: 273-81, 2011.

45. Goodarzi AA, Jeggo P, Lobrich $M$. The influence of heterochromatin on DNA double strand break repair: Getting the strong, silent type to relax. DNA Repair (Amst) 9: 1273-82, 2010.

46. Goodhead DT. Initial events in the cellular effects of ionizing radiations: clustered damage in DNA. International Journal of Radiation Biology 65: 7-17, 1994.

47. Grawunder U, Wilm M, Wu X, Kulesza P, Wilson TE, Mann M, Lieber MR. Activity of DNA ligase IV stimulated by complex formation with XRCC4 protein in mammalian cells. Nature 388: 492-5, 1997. 
Kavanagh et al.

48. Grawunder U, Zimmer D, Leiber MR. DNA ligase IV binds to XRCC4 via a motif located between rather than within its BRCT domains. Curr Biol 8: 8736, 1998.

49. Gulston M, de Lara C, Jenner T, Davis E, O'Neill P. Processing of clustered DNA damage generates additional double-strand breaks in mammalian cells post-irradiation. Nucleic Acids Res 32: 1602-9, 2004.

50. Guo Z, Kozlov S, Lavin MF, Person MD, Paull TT. ATM activation by oxidative stress. Science 330: 517-21, 2010.

51. Haber JE. DNA repair. Gatekeepers of recombination. Nature 398: 665, 667, 1999.

52. Hahn SA, Greenhalf B, Ellis I, Sina-Frey M, Rieder H, Korte B, Gerdes B, Kress R, Ziegler A, Raeburn JA, Campra D, Grutzmann R, Rehder $H$, Rothmund M, Schmiegel W, Neoptolemos JP, Bartsch DK. BRCA2 germline mutations in familial pancreatic carcinoma. J Natl Cancer Inst 95: 214-21, 2003.

53. Hendrickson EA. Cell-cycle regulation of mammalian DNA double-strandbreak repair. American Journal of Human Genetics 61: 795-800, 1997.

54. Hess CJ, Ameziane N, Schuurhuis GJ, Errami A, Denkers F, Kaspers GJ, Cloos J, Joenje H, Reinhardt D, Ossenkoppele GJ, Zwaan CM, Waisfisz Q. Hypermethylation of the FANCC and FANCL promoter regions in sporadic acute leukaemia. Cell Oncol 30: 299-306, 2008.

55. Holliday R. Recombination and meiosis. Philosophical Transactions of the Royal Society of London B Biological Sciences 277: 359-70, 1977.

56. Ip SC, Rass U, Blanco MG, Flynn HR, Skehel JM, West SC. Identification of Holliday junction resolvases from humans and yeast. Nature 456: 357-61, 2008.

57. Jackson SP. Sensing and repairing DNA double-strand breaks. Carcinogenesis 23: 687-96, 2002.

58. Jazayeri A, Falck J, Lukas C, Bartek J, Smith GC, Lukas J, Jackson SP. ATM- and cell cycle-dependent regulation of ATR in response to DNA doublestrand breaks. Nature Cell Biology 8: 37-45, 2006.

59. Johzuka K, Ogawa H. Interaction of Mre11 and Rad50: two proteins required for DNA repair and meiosis-specific double-strand break formation in Saccharomyces cerevisiae. Genetics 139: 1521-32, 1995.

60. Jones $S$, Hruban RH, Kamiyama M, Borges $M$, Zhang X, Parsons DW, Lin JC, Palmisano E, Brune K, Jaffee EM, lacobuzio-Donahue CA, Maitra A, Parmigiani G, Kern SE, Velculescu VE, Kinzler KW, Vogelstein B, Eshleman JR, Goggins M, Klein AP. Exomic sequencing identifies PALB2 as a pancreatic cancer susceptibility gene. Science 324: 217, 2009.

61. Junop MS, Modesti M, Guarne A, Ghirlando R, Gellert M, Yang W. Crystal structure of the Xrcc4 DNA repair protein and implications for end joining. Embo Journal 19: 5962-70, 2000.

62. Karimi-Busheri F, Rasouli-Nia A, Allalunis-Turner J, Weinfeld M. Human polynucleotide kinase participates in repair of DNA double-strand breaks by nonhomologous end joining but not homologous recombination. Cancer Res 67: 6619-25, 2007.

63. Kaye SB, Lubinski J, Matulonis U, Ang JE, Gourley C, Karlan BY, Amnon A, Bell-McGuinn KM, Chen LM, Friedlander M, Safra T, Vergote I, Wickens M, Lowe ES, Carmichael J, Kaufman B. Phase II, open-label, randomized, multicenter study comparing the efficacy and safety of olaparib, a poly (ADPribose) polymerase inhibitor, and pegylated liposomal doxorubicin in patients with BRCA1 or BRCA2 mutations and recurrent ovarian cancer. J Clin Oncol 30: 372-9, 2012.

64. Kennedy RD, Chen CC, Stuckert P, Archila EM, De la Vega MA, Moreau LA, Shimamura A, D'Andrea AD. Fanconi anemia pathway-deficient tumor cells 
are hypersensitive to inhibition of ataxia telangiectasia mutated. J Clin Invest 117: 1440-9, 2007.

65. Kennedy RD, D'Andrea AD. The Fanconi Anemia/BRCA pathway: new faces in the crowd. Genes Dev 19: 2925-40, 2005.

66. Khanna KK. Cancer risk and the ATM gene: a continuing debate. $\mathrm{J}$ Natl Cancer Inst 92: 795-802, 2000.

67. Kim JS, Krasieva TB, Kurumizaka H, Chen DJ, Taylor AM, Yokomori K. Independent and sequential recruitment of NHEJ and HR factors to DNA damage sites in mammalian cells. J Cell Biol 170: 341-7, 2005.

68. Kitagawa R, Bakkenist CJ, McKinnon PJ, Kastan MB. Phosphorylation of SMC1 is a critical downstream event in the ATM-NBS1-BRCA1 pathway. Genes Dev 18: 1423-38, 2004.

69. Kortmann U, McAlpine JN, Xue H, Guan J, Ha G, Tully S, Shafait S, Lau A, Cranston AN, O'Connor MJ, Huntsman DG, Wang Y, Gilks CB. Tumor growth inhibition by olaparib in BRCA2 germline-mutated patient-derived ovarian cancer tissue xenografts. Clin Cancer Res 17: 783-91, 2011.

70. Kryston TB, Georgiev AB, Pissis P, Georgakilas AG. Role of oxidative stress and DNA damage in human carcinogenesis. Mutat Res 711: 193-201, 2011.

71. Kuroda S, Urata Y, Fujiwara T. Ataxia-telangiectasia mutated and the Mre11Rad50-NBS1 complex: promising targets for radiosensitization. Acta Med Okayama 66: 83-92, 2012.

72. Lindahl T. Instability and Decay of the Primary Structure of DNA. Nature 362: 709-715, 1993.

73. Lobrich $\mathrm{M}$, Jeggo PA. Harmonising the response to DSBs: a new string in the ATM bow. DNA Repair (Amst) 4: 749-59, 2005.

74. Luce A, Courtin A, Levalois C, Altmeyer-Morel S, Romeo PH, Chevillard S, Lebeau J. Death receptor pathways mediate targeted and non-targeted effects of ionizing radiations in breast cancer cells. Carcinogenesis 30: 432-9, 2009.

75. Lyng FM, Howe OL, McClean B. Reactive oxygen species-induced release of signalling factors in irradiated cells triggers membrane signalling and calcium influx in bystander cells. Int J Radiat Biol 87: 683-95, 2011.

76. Mahaney BL, Meek K, Lees-Miller SP. Repair of ionizing radiation-induced DNA double-strand breaks by non-homologous end-joining. Biochemical Journal 417: 639-50, 2009.

77. Martin-Guerrero I, Enjuanes A, Richter J, Ammerpohl O, Colomer D, Ardanaz M, Marco F, Salas A, Campo E, Siebert R, Garcia-Orad A. A putative "hepitype" in the ATM gene associated with chronic lymphocytic leukemia risk. Genes Chromosomes Cancer 50: 887-95, 2011.

78. Masson JY, Tarsounas MC, Stasiak AZ, Stasiak A, Shah R, Mcllwraith MJ, Benson FE, West SC. Identification and purification of two distinct complexes containing the five RAD51 paralogs. Genes Dev 15: 3296-307, 2001.

79. Matsuoka S, Ballif BA, Smogorzewska A, McDonald ER, 3rd, Hurov KE, Luo J, Bakalarski CE, Zhao Z, Solimini N, Lerenthal Y, Shiloh Y, Gygi SP, Elledge SJ. ATM and ATR substrate analysis reveals extensive protein networks responsive to DNA damage. Science 316: 1160-6, 2007.

80. McVey M, Lee SE. MMEJ repair of double-strand breaks (director's cut): deleted sequences and alternative endings. Trends in Genetics 24: 529-38, 2008.

81. Meek K, Dang V, Lees-Miller SP. DNA-PK: the means to justify the ends? Adv Immunol 99: 33-58, 2008.

82. Meng AX, Jalali F, Cuddihy A, Chan N, Bindra RS, Glazer PM, Bristow RG. Hypoxia down-regulates DNA double strand break repair gene expression in prostate cancer cells. Radiother Oncol 76: 168-76, 2005. 
Kavanagh et al.

83. Mitchell JB, Choudhuri R, Fabre K, Sowers AL, Citrin D, Zabludoff SD, Cook $\mathrm{JA}$. In vitro and in vivo radiation sensitization of human tumor cells by a novel checkpoint kinase inhibitor, AZD7762. Clin Cancer Res 16: 2076-84, 2010.

84. Morgan MA, Parsels LA, Zhao L, Parsels JD, Davis MA, Hassan MC, Arumugarajah S, Hylander-Gans L, Morosini D, Simeone DM, Canman CE, Normolle DP, Zabludoff SD, Maybaum J, Lawrence TS. Mechanism of radiosensitization by the Chk1/2 inhibitor AZD7762 involves abrogation of the G2 checkpoint and inhibition of homologous recombinational DNA repair. Cancer Res 70: 4972-81, 2010.

85. Mukherjee B, Tomimatsu N, Amancherla K, Camacho CV, Pichamoorthy N, Burma S. The dual PI3K/mTOR inhibitor NVP-BEZ235 is a potent inhibitor of ATM- and DNA-PKCs-mediated DNA damage responses. Neoplasia 14: 3443, 2012.

86. Nick McElhinny SA, Havener JM, Garcia-Diaz M, Juarez R, Bebenek K, Kee $B L$, Blanco L, Kunkel TA, Ramsden DA. A gradient of template dependence defines distinct biological roles for family $X$ polymerases in nonhomologous end joining. Mol Cell 19: 357-66, 2005.

87. Okayasu R. Repair of DNA damage induced by accelerated heavy ions--a mini review. International Journal of Cancer 130: 991-1000, 2012.

88. Okayasu R, Okada M, Okabe A, Noguchi M, Takakura K, Takahashi S. Repair of DNA damage induced by accelerated heavy ions in mammalian cells proficient and deficient in the non-homologous end-joining pathway. Radiation Research 165: 59-67, 2006.

89. Olcina M, Lecane PS, Hammond EM. Targeting hypoxic cells through the DNA damage response. Clin Cancer Res 16: 5624-9, 2010.

90. Park EJ, Chan DW, Park JH, Oettinger MA, Kwon J. DNA-PK is activated by nucleosomes and phosphorylates $\mathrm{H} 2 \mathrm{AX}$ within the nucleosomes in an acetylation-dependent manner. Nucleic Acids Res 31: 6819-27, 2003.

91. Pasi F, Facoetti A, Nano R. IL-8 and IL-6 bystander signalling in human glioblastoma cells exposed to gamma radiation. Anticancer Res 30: 2769-72, 2010.

92. Paull TT. Saving the ends for last: the role of pol mu in DNA end joining. $\mathrm{Mol}$ Cell 19: 294-6, 2005.

93. Pires IM, Olcina MM, Anbalagan S, Pollard JR, Reaper PM, Charlton PA, McKenna WG, Hammond EM. Targeting radiation-resistant hypoxic tumour cells through ATR inhibition. Br J Cancer 107: 291-9, 2012.

94. Polo SE, Jackson SP. Dynamics of DNA damage response proteins at DNA breaks: a focus on protein modifications. Genes and Development 25: 40933, 2011.

95. Prise KM, Folkard M, Newman HC, Michael BD. Effect of radiation quality on lesion complexity in cellular DNA. International Journal of Radiation Biology 66: 537-42, 1994.

96. Prise KM, O'Sullivan JM. Radiation-induced bystander signalling in cancer therapy. Nat Rev Cancer 9: 351-60, 2009.

97. Rahman N, Seal S, Thompson D, Kelly P, Renwick A, Elliott A, Reid S, Spanova K, Barfoot R, Chagtai T, Jayatilake H, McGuffog L, Hanks S, Evans DG, Eccles D, Easton DF, Stratton MR. PALB2, which encodes a BRCA2interacting protein, is a breast cancer susceptibility gene. Nat Genet 39: 1657, 2007.

98. Renwick A, Thompson D, Seal S, Kelly P, Chagtai T, Ahmed M, North B, Jayatilake H, Barfoot R, Spanova K, McGuffog L, Evans DG, Eccles D, Easton DF, Stratton MR, Rahman N. ATM mutations that cause ataxiatelangiectasia are breast cancer susceptibility alleles. Nat Genet 38: 873-5, 2006. 
Kavanagh et al.

99. Reynolds P, Anderson JA, Harper JV, Hill MA, Botchway SW, Parker AW, O'Neill P. The dynamics of Ku70/80 and DNA-PKcs at DSBs induced by ionizing radiation is dependent on the complexity of damage. Nucleic Acids Res 40: 10821-31, 2012.

100. Riballo E, Kuhne M, Rief N, Doherty A, Smith GC, Recio MJ, Reis C, Dahm K, Fricke A, Krempler A, Parker AR, Jackson SP, Gennery A, Jeggo PA, Lobrich M. A pathway of double-strand break rejoining dependent upon ATM, Artemis, and proteins locating to gamma-H2AX foci. Mol Cell 16: 715-24, 2004.

101. Richard DJ, Bolderson E, Cubeddu L, Wadsworth RI, Savage K, Sharma GG, Nicolette ML, Tsvetanov S, Mcllwraith MJ, Pandita RK, Takeda S, Hay RT, Gautier J, West SC, Paull TT, Pandita TK, White MF, Khanna KK. Singlestranded DNA-binding protein hSSB1 is critical for genomic stability. Nature 453: 677-81, 2008.

102. Richard DJ, Savage K, Bolderson E, Cubeddu L, So S, Ghita M, Chen DJ, White MF, Richard K, Prise KM, Schettino G, Khanna KK. hSSB1 rapidly binds at the sites of DNA double-strand breaks and is required for the efficient recruitment of the MRN complex. Nucleic Acids Res 39: 1692-702, 2011.

103. Richard DJ, Savage K, Bolderson E, Cubeddu L, So S, Ghita M, Chen DJ, White MF, Richard K, Prise KM, Schettino G, Khanna KK. hSSB1 rapidly binds at the sites of DNA double-strand breaks and is required for the efficient recruitment of the MRN complex. Nucleic Acids Research 39: 1692-702, 2011.

104. Riesterer O, Matsumoto F, Wang L, Pickett J, Molkentine D, Giri U, Milas L, Raju U. A novel Chk inhibitor, XL-844, increases human cancer cell radiosensitivity through promotion of mitotic catastrophe. Invest New Drugs 29: 514-22, 2011.

105. Rogakou EP, Pilch DR, Orr AH, Ivanova VS, Bonner WM. DNA doublestranded breaks induce histone H2AX phosphorylation on serine 139. Journal of Biological Chemistry 273: 5858-5868, 1998.

106. Roots R, Yang TC, Craise L, Blakely EA, Tobias CA. Impaired repair capacity of DNA breaks induced in mammalian cellular DNA by accelerated heavy ions. Radiat Res 78: 38-49, 1979.

107. Sartori AA, Lukas C, Coates J, Mistrik M, Fu S, Bartek J, Baer R, Lukas J, Jackson SP. Human CtIP promotes DNA end resection. Nature 450: 509-14, 2007.

108. Savitsky K, Bar-Shira A, Gilad S, Rotman G, Ziv Y, Vanagaite L, Tagle DA, Smith S, Uziel T, Sfez S, Ashkenazi M, Pecker I, Frydman M, Harnik R, Patanjali SR, Simmons A, Clines GA, Sartiel A, Gatti RA, Chessa L, Sanal O, Lavin MF, Jaspers NG, Taylor AM, Arlett CF, Miki T, Weissman SM, Lovett M, Collins FS, Shiloh Y. A single ataxia telangiectasia gene with a product similar to PI-3 kinase. Science 268: 1749-53, 1995.

109. Shao C, Folkard M, Prise KM. Role of TGF-beta1 and nitric oxide in the bystander response of irradiated glioma cells. Oncogene 27: 434-40, 2008.

110. Shrivastav M, De Haro LP, Nickoloff JA. Regulation of DNA double-strand break repair pathway choice. Cell Res 18: 134-47, 2008.

111. Singleton BK, Torres-Arzayus MI, Rottinghaus ST, Taccioli GE, Jeggo PA. The $\mathrm{C}$ terminus of Ku80 activates the DNA-dependent protein kinase catalytic subunit. Molecular and Cellular Biology 19: 3267-77, 1999.

112. Solyom S, Winqvist R, Nikkila J, Rapakko K, Hirvikoski P, Kokkonen H, Pylkas K. Screening for large genomic rearrangements in the FANCA gene reveals extensive deletion in a Finnish breast cancer family. Cancer Lett 302: 113-8, 2011. 
Kavanagh et al.

113. Stenerlow B, Hoglund E, Elmroth K, Karlsson KH, Radulescu I. Radiation quality dependence of DNA damage induction. Radiation Protection Dosimetry 99: 137-41, 2002.

114. Stewart GS, Wang B, Bignell CR, Taylor AM, Elledge SJ. MDC1 is a mediator of the mammalian DNA damage checkpoint. Nature 421: 961-6, 2003.

115. Summers KC, Shen F, Sierra Potchanant EA, Phipps EA, Hickey RJ, Malkas LH. Phosphorylation: the molecular switch of double-strand break repair. Int J Proteomics 2011: 373816.

116. Suzuki M, Suzuki K, Kodama S, Watanabe M. Interstitial chromatin alteration causes persistent p53 activation involved in the radiation-induced senescence-like growth arrest. Biochem Biophys Res Commun 340: 145-50, 2006.

117. Suzuki M, Suzuki K, Kodama S, Watanabe M. Phosphorylated histone H2AX foci persist on rejoined mitotic chromosomes in normal human diploid cells exposed to ionizing radiation. Radiat Res 165: 269-76, 2006.

118. Tanaka T, Halicka HD, Huang X, Traganos F, Darzynkiewicz Z. Constitutive histone H2AX phosphorylation and ATM activation, the reporters of DNA damage by endogenous oxidants. Cell Cycle 5: 1940-5, 2006.

119. Thompson D, Duedal S, Kirner J, McGuffog L, Last J, Reiman A, Byrd P, Taylor M, Easton DF. Cancer risks and mortality in heterozygous ATM mutation carriers. J Natl Cancer Inst 97: 813-22, 2005.

120. Uematsu N, Weterings E, Yano K, Morotomi-Yano K, Jakob B, TaucherScholz G, Mari PO, van Gent DC, Chen BP, Chen DJ. Autophosphorylation of DNA-PKCS regulates its dynamics at DNA double-strand breaks. J Cell Biol 177: 219-29, 2007.

121. Ugenskiene R, Prise K, Folkard M, Lekki J, Stachura Z, Zazula M, Stachura J. Dose response and kinetics of foci disappearance following exposure to high- and low-LET ionizing radiation. International Journal of Radiation Biology 85: 872-882, 2009.

122. Uziel T, Lerenthal Y, Moyal L, Andegeko Y, Mittelman L, Shiloh Y. Requirement of the MRN complex for ATM activation by DNA damage. EMBO J 22: 5612-21, 2003.

123. van den Bosch M, Bree RT, Lowndes NF. The MRN complex: coordinating and mediating the response to broken chromosomes. EMBO Rep 4: 844-9, 2003.

124. van der Groep $P$, Hoelzel $M$, Buerger $H$, Joenje $H$, de Winter JP, van Diest PJ. Loss of expression of FANCD2 protein in sporadic and hereditary breast cancer. Breast Cancer Res Treat 107: 41-7, 2008.

125. van Vuurden DG, Hulleman E, Meijer OL, Wedekind LE, Kool M, Witt H, Vandertop PW, Wurdinger T, Noske DP, Kaspers GJ, Cloos J. PARP inhibition sensitizes childhood high grade glioma, medulloblastoma and ependymoma to radiation. Oncotarget 2: 984-96, 2011.

126. Vaupel $\mathrm{P}$, Mayer A. Hypoxia in cancer: significance and impact on clinical outcome. Cancer Metastasis Rev 26: 225-39, 2007.

127. Walker JR, Corpina RA, Goldberg J. Structure of the Ku heterodimer bound to DNA and its implications for double-strand break repair. Nature 412: 607$14,2001$.

128. Wang H, Rosidi B, Perrault R, Wang M, Zhang L, Windhofer F, Iliakis G. DNA ligase III as a candidate component of backup pathways of nonhomologous end joining. Cancer Res 65: 4020-30, 2005.

129. Wang M, Wu W, Rosidi B, Zhang L, Wang H, lliakis G. PARP-1 and Ku compete for repair of DNA double strand breaks by distinct NHEJ pathways. Nucleic Acids Res 34: 6170-82, 2006.

130. Ward IM, Chen J. Histone H2AX is phosphorylated in an ATR-dependent manner in response to replicational stress. J Biol Chem 276: 47759-62, 2001. 
Kavanagh et al.

131. Ward IM, Minn K, Jorda KG, Chen J. Accumulation of checkpoint protein 53BP1 at DNA breaks involves its binding to phosphorylated histone H2AX. J Biol Chem 278: 19579-82, 2003.

132. Ward JF. The complexity of DNA damage: relevance to biological consequences. International Journal of Radiation Biology 66: 427-32, 1994.

133. Weber KJ, Flentje M. Lethality of heavy ion-induced DNA double-strand breaks in mammalian cells. International Journal of Radiation Biology 64: 169-78, 1993.

134. Williamson CT, Muzik H, Turhan AG, Zamo A, O'Connor MJ, Bebb DG, LeesMiller SP. ATM deficiency sensitizes mantle cell lymphoma cells to poly(ADPribose) polymerase-1 inhibitors. Mol Cancer Ther 9: 347-57, 2010.

135. Wu CY, Kang HY, Yang WL, Wu J, Jeong YS, Wang J, Chan CH, Lee SW, Zhang $X$, Lamothe $B$, Campos AD, Darnay BG, Lin HK. Critical role of monoubiquitination of histone $\mathrm{H} 2 \mathrm{AX}$ protein in histone $\mathrm{H} 2 \mathrm{AX}$ phosphorylation and DNA damage response. Journal of Biological Chemistry 286: 30806-15, 2011.

136. Xu B, O'Donnell AH, Kim ST, Kastan MB. Phosphorylation of serine 1387 in Brca1 is specifically required for the Atm-mediated S-phase checkpoint after ionizing irradiation. Cancer Res 62: 4588-91, 2002.

137. Yang D, Khan S, Sun Y, Hess K, Shmulevich I, Sood AK, Zhang W. Association of BRCA1 and BRCA2 mutations with survival, chemotherapy sensitivity, and gene mutator phenotype in patients with ovarian cancer. JAMA 306: 1557-65, 2011.

138. Yuan J, Chen J. MRE11-RAD50-NBS1 complex dictates DNA repair independent of H2AX. Journal of Biological Chemistry 285: 1097-104, 2010.

139. Zhang X, Zhu Y, Geng L, Wang H, Legerski RJ. Artemis is a negative regulator of p53 in response to oxidative stress. Oncogene 28: 2196-204, 2009.

140. Zhao $\mathrm{H}$, Piwnica-Worms H. ATR-mediated checkpoint pathways regulate phosphorylation and activation of human Chk1. Mol Cell Biol 21: 4129-39, 2001.

141. Zirkle RE, Tobias CA. Effects of ploidy and linear energy transfer on radiobiological survival curves. Archives of Biochemistry and Biophysics 47: 282-306, 1953.

142. Ziv Y, Bielopolski D, Galanty Y, Lukas C, Taya Y, Schultz DC, Lukas J, Bekker-Jensen S, Bartek J, Shiloh Y. Chromatin relaxation in response to DNA double-strand breaks is modulated by a novel ATM- and KAP-1 dependent pathway. Nat Cell Biol 8: 870-6, 2006.

143. Zou Y, Liu Y, Wu X, Shell SM. Functions of human replication protein $A$ (RPA): from DNA replication to DNA damage and stress responses. J Cell Physiol 208: 267-73, 2006. 
Kavanagh et al.

\section{Figure Legends}

Figure 1. Introduction to radiation induced DNA damage. Ionizing radiation causes many different types of damage to DNA, by direct and indirect routes. That damage ranges from 'simple' lesions such as base or sugar modifications, DNA-protein interactions; to DNA crosslinks and single strand breaks to more 'complex' lesions such as DNA double stand breaks.

Figure 2. Pathways sensing DNA DSBs. DNA double strand breaks are initially recognised by sensor proteins, such as the MRN complex, MDC1 and $\mathrm{YH} 2 \mathrm{AX}$. These sensor proteins activate downstream transducer proteins including ATM, ATR and 53BP1, which function to activate effector proteins, resulting in cell cycle arrest, DNA damage repair or cell death pathways, if the damage cannot be repaired.

Figure 3. DSB repair pathways. DNA double strand breaks are repaired predominantly by one of two pathways. 1) Homologous recombination (HR) requires a homologous sister chromatid as a template from which to rebuild sections of DNA lost at break sites. This method has high fidelity. 2) Non-homologous end-joining (NHEJ) repair can be employed in the presence or absence of a sister chromatid. In this repair process ragged ends of DNA at sites of lesions are first tethered together then processes and any gaps filled before the ends are ligated to complete repair.

Figure 4. DSB repair and radiation quality. DNA DSBs can be detected by immunofluoresence using antibodies to factors recruited to, or modified at breaks sites, such as $\mathrm{yH} 2 \mathrm{AX}$. Examples of $\mathrm{yH} 2 \mathrm{AX}$ foci induced by low LET radiation such as $X$-rays (a) and high LET radiation such as helium ions (b) are shown. Analysing the kinetics of foci disappearance and can indicate the complexity of DNA lesions caused by radiations of different quality. A schematic illustrating the difference in foci resolution kinetics between high and low LET radiations is shown in (c).

Figure 5. DSB repair and oxidative stress. DNA double strand breaks can occur as a consequence of oxidative stress within the cell or as a downstream effect of bystander signaling by chemokines, cytokines or death ligands released from other cells. This damage is recognised primarily by ATR, with ATM acting downstream in the pathway.

Figure 6. Synthetic lethality. Cells possess numerous DNA repair pathways. In the case of double-strand break repair, these pathways include HR and NHEJ. a) When both pathways are intact cells can efficiently repair and DNA damage encountered. If 
Kavanagh et al.

one of the pathways is lost, cells can rely on the second pathway to repair damage and allow the cells to survive. b) Inhibitors targeting one of the pathways (denoted $x$ ) have little effect on DNA repair and cell survival when the other pathway is intact. However, if one of the pathways is mutated, inhibition of the other pathway results in the cell being unable to repair damage and cell death. 
Figure I

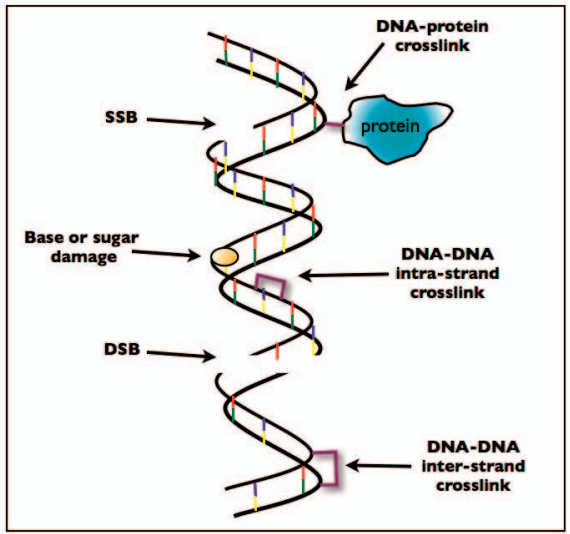


Figure 2

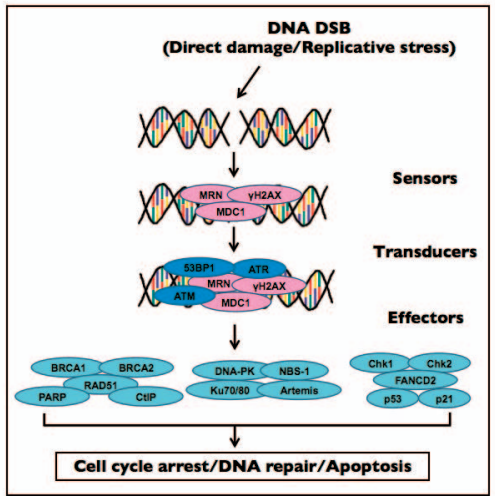


Figure 3.1

\section{Homologous Recombination}

1.

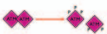

In

2.

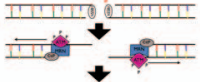

3.

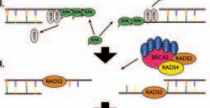

5.

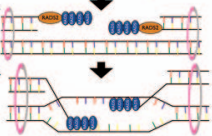

7.

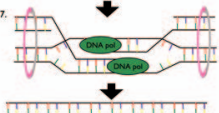

Figure 3.2

Non-homologous end joining

2.

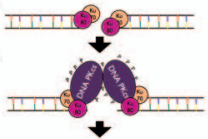

3.

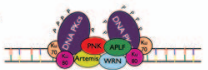

4.

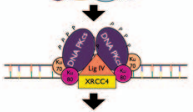

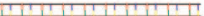




\section{Figure 5}

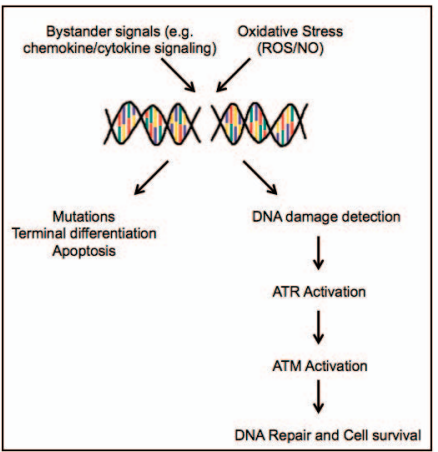




\section{Figure 6}

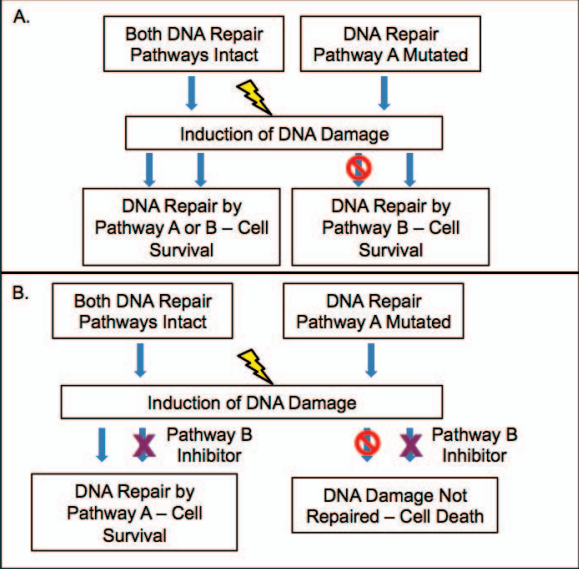

